\title{
The end of the Kingdom of Judah and its echoes in the Jewish calendar
}

\section{[Konec Judskeho kralovstvi a jeho ozveny v zidovskem kalendari]}

\author{
Marie Roubalova - Olga A. Kalugina - Roman Kralik - Peter Kondrla
}

DOI: 10.18355/XL.2020.13.03.16

\begin{abstract}
This article analyzes exegetically and historically the end of the Kingdom of Judah, identifying and subsequently interpreting its echoes in the Jewish Calendar. The books of TaNaKh serve as the primary resource. The fate of the chosen people of Israel was intricately linked to the presence of God in the midst of His people as represented by the Temple. Therefore, the loss of the Jerusalem Temple entailed profound feelings of loss, forsakenness, even hopelessness. The accompanying loss of land and basic religious and political institutions engendered a cycle of mourning and repentance at the end of which a glimpse of hope emerges of a future renewal of Jerusalem. The cycle of excruciating sorrow, mournful repentance, and signs of hopeful renewal are reflected in the liturgy and Jewish Calendar.

Key words: Jewish calendar, the Kingdom of Judah, chosen People, Jerusalem Temple
\end{abstract}

\begin{abstract}
Abstrakt
Předložená studie analyzuje exegeticky a historicky konec Judského království a identifikuje a následně interpretuje jeho ozvěny $\mathrm{v}$ židovském kalendáři. Knihy Tanachu slouží jako primární zdroj. Osud vyvoleného lidu Izraele byl složitě spojen s Boží přítomností uprostřed jeho lidu, jak jej reprezentoval chrám. Ztráta Jeruzalémského chrámu proto znamenala hluboké pocity ztráty, opuštění a beznaděje. Doprovodná ztráta země a základní náboženské a politické instituce vyvolaly cyklus smutku a pokání, na jehož konci se objeví záblesk naděje pro budoucí obnovu Jeruzaléma. Cyklus nesnesitelného smutku, truchlivého pokání a známek nadějné obnovy se odráží v liturgii a židovském kalendáři.

Klíčová slova: Židovský kalendář, Judské království, vyvolení lidé, Jeruzalémský chrám

\section{Úvod}

Tanach čtenáře seznamuje se svou teologickou interpretací konce Judského království v knihách Melachim a v knihách Divrej hajamim. (Divecky, 2010: 139). Bez této teologické interpretace by dějiny Judska neměly pro rabínský judaismus žádný smysl: „Za zdánlivě presnými záznamy, jež se zdaji být historicky spolehlivé, se skrývají konkrétni teologické a ideologické zájmy. Ty jsou vyjádřeny jak tvrzením o legitimitě nebo naopak nelegitimni konáni určité postavy krále, tak pohybováním vybraným vladařem nejen v čase, ale také v prostoru." (Capek, 2018: 118).

Podání výše zmíněných knih dokresluje v Tanachu kniha proroka Jirmejahu a kniha Ejcha. (více: Benes, 2020). Společným tématem obou je prrímá vazba mezi hříchem a utrpením (obdobně jako v Devarim 28). Vyvolený lid porušil smlouvu, kterou s ním uzavřel Hospodin, proto je zodpovědný za nastalou katastrofu. (Noth, 1950: 207). Zkáza však není posledním slovem, protože smlouva zrušena nebyla.
\end{abstract}

\section{Historické pozadí konce Judského království}

Malé, poměrně chudé Judsko pocítilo bezpoyby velké zděšení již při zániku svého bohatšího a vojensky lépe vybaveného severního souseda. (Divecky, 2010: 108-109, Bic, 1980: 282). Po ztrátě severních kmenů zůstává národem, který má právo na 
Zaslíbenou zemi již jen obyvatelstvo Judska (z jehož pohledu jsou dějiny interpretovány). Judští králové se snaží zabránit tomu, aby byl osud jejich země stejný jako osud Izraele. (Finkelstein, 2016: 191). Mnozí spoléhají na koalice se sousedními státy. Proroci a kněží však vidí tyto snahy jako zbytečné. Malé Judsko nemůže svou vlastní silou vzdorovat mocným veleříším. Jeho jedinou nadějí je spojit se s tím, kdo je Pánem celého světa. Proroci volají po věrnosti Bohu a zachovávání Božího učení, což jako jediné může přinést záchranu. Nestačí pouze vnější projevy Chizkijášovy a Jošijášovy reformy (ničení vyobrazení, posvátných stromů a návrší, pobíjení modlářských kněží) je třeba vnitřní změna srdce člověka, které bylo dosud umíněné a vzpurné.

Pro Hospodinovy vyznavače jsou všechny národ - velké (Egypt, Asýrie, Novobabylónská říše apod.) i malé (Edóm, Moáb, Amón, Pelištea apod.), v jejichž kontextu se odehrává jejich historie, pouze nástrojem, kterým Hospodin zasahuje do jejich vlastních dějin. Pokud jde o konec Judského království, byl jedním z nejvýznamnějších Božích „nástrojü“ král Nebúkadnesar, který je v knize Jirmejahu nazván Hospodinovým služebníkem (Jr 25,9). Tento Boží služebník zasáhne z důvodu neustálého porušování smlouvy s Bohem. Zkáza Jeruzaléma bude tak velká, že: „, toto město bude vzbuzovat úděs a posměch; každý kolemjdouci nad všemi jeho ranami posměšně zasykne úžasem " (Jr 19,8). Události, které k této zkáze bezprostředně vedly, se začínají řetězit přibližně od roku 609 př.o.l. V tomto roce zemřel zbožný spravedlivý charismatický král Jehošijaš (2 Kr 22-23,30), který v Judsku prosazoval náboženské reformy podporované Knihou zákona nalezenou r. 622/621 př.o.l. během oprav v Chrámu (2 Pa 34,3-7; $2 \mathrm{Kr} 23$ ). Zbožný král Jehošijáš byl těžce raněn šípem na počátku bitvy u Megida (609/8 př.o.1.), když se postavil egyptskému faraonovi Nechovi/Nékovi II., který vytáhl na sever, aby vojensky pomohl Asýrii př́ípadně, aby získal (resp. obnovil) slib věrnosti od vazalských států po smrti svého otce Psammtéka, který tyto státy ovládal a jehož smrtí se tyto závazky staly neplatné. (Finkelstein, Silberman, 2007: 258). Horlivost krále Jehošijáše pro Hospodina dávala tomuto střetu kromě roviny vojenské také rovinu náboženskou: „Poprvé od exodu zkřižili Židé a Egypt'ané zbraně ve velké bitvě na otevřeném poli... " (Herzog -Gichon, 1999: 111-112). Pro Hospodinova vyznavače šlo o střetnutí dvou světů - světa života, do kterého se vystupuje („ole“) a světa posvětí, do kterého se sestupuje (,jored“).

Po převozu do Jeruzaléma král Jehošijaš svému zranění podlehl (2 $\mathrm{Pa} 35,24)$. Tanach na neúspěch králova počínání a náboženské reformy odpovídá odkazem na bezbožného krále Menašeho (syn zbožného krále Chizkijáše): „Avšak Hospodin neupustil od svého velikého planoucího hněvu, kterým vzplanul proti Judovi pro všechny urážky, jimiž ho urážel Menaše." (2 Kr 23,26). Jeho hříchy způsobily všechny následující pohromy, které vyvolený lid postihl. Nástupci Jehošijaše $\mathrm{v}$ reformách nepokračovali.

Po smrti krále Jehošijaše dosadilo svobodné obyvatelstvo země - ,am haarec“ (2 Kr $23,30 ; 21,24)$ na trůn jeho syna Joachaze (609 př. o.1.) a to i přesto, že nebyl prvorozeným synem (Noth, 1950: 206). Joachaz vládl pouze tři měsíce (v době, kdy Necho II. řešil problémy na severu u Charanu). Po svém návratu do Judska faraon Necho II. uvalil na zemi za královy proti egyptské postoje velkou pokutu, kterou musel zaplatit jeho nástupce ( $2 \mathrm{Kr} 23,35)$. Krále Joachaze sesadil a odvlekl do Egypta (609 př.o.1.), kde zemřel (2 Kr 23,31-35). Faraón Necho II. „,vrátil vládu Davidovcu do předjoziášovských poměrů, omezil ji na městský stát Jeruzalém a starý stát Juda... územi někdejšího státu Izrael dal spravovat jako egyptské provincie. “ (Noth, 1950: 206).

Po epizodní vládě Joachaze nastoupil na judský trůn jeho starší bratr Eljakim. Faraon mu na znamení své svrchovanosti změnil jméno na Jehojakim (Jójakím). (2 Kr 23,34; srv. $2 \mathrm{~Pa} 36,4)$. Jehojakim vládl v Judsku poměrně dlouho (608 až 598 př.o.l.). Byl prvorozeným synem Jehošiaše, což mu dávalo velké naděje na trůn (2 Kr 23,36-24,7).

XLinguae, Volume 13 Issue 3, June 2020, ISSN 1337-8384, ISSN 2453-711X 
Podle rabínské tradice však na něj po smrti svého otce neusedl, protože nebyl považován za vhodného k vykonávání královské funkce. Jakoby ani nebyl synem zbožného Jehošijaše. V Tanachu se mluví o jeho „ohavnostech“, které jsou zapsány v (nedochované) Knize králů izraelských a judských (2 Pa 36,8). Jak strašná byla jeho vláda, dosvědčuje rovněž prorok Jirmejahu. Jehojakim byl slabým, bezbožným, nespravedlivým, chamtivým a despotickým vládcem: „Nebyl uctivý ani k Bohu, ani nebyl laskavý k lidem. “ (Josephus, Judean Antiquities. X.83) Jeho vládu provázel útlak, krveprolití a sociální nespravedlnost. Dopouštěl se ,toho, co bylo zlé v očich Hospodina" (2 $\mathrm{Pa} 36,5$; srv. Jr 52,2). Prosazoval modloslužbu a poskvrnil dům Hospodinův. Pro stavbu paláce král využíval nucené práce, což vzbudilo mezi obyvatelstvem velkou nelibost. (Potok, 2002: 174-175). Na lid uvalil tvrdé daně, aby byl schopen financovat stavbu královských budov a aby mohl platit vysoký tribut (sto talentů stř́bra a talent zlata), který na Judsko uvalili Egypt’ané. Pohrdal slovy proroků a krutě proti nim vystupoval (Jr 26; 36). Svitek se slovy proroka Jirmejahu nechal spálit (Jr 36,23.29.30). Prorokům, kteří veřejně promluvili proti králi, šlo za jeho vlády o život. Urijahu ben Šemajahu, prorok Hospodinův z Kirjat-hajearim, který to učinil, byl přivlečen z Egypta, kde marně hledal ochranu před svým králem. Na králův rozkaz byl po návratu nelítostně zabit. Jeho tělo bylo ponecháno bez řádného pohřbu pohozené u hrobů prostého lidu (Jr 26,1-24). Prorokova snaha hledat pomoc proti krvelačnému králi právě v Egyptě byla bláhová. Vždyt' Jehojakim se stál králem právě $\mathrm{z}$ vůle Egypta. $\mathrm{V}$ židovských legendách je král Jehojakim vyobrazen ještě v horším světle než $\mathrm{v}$ Tanachu. Historikové přináší pozitivnější pohled na období vlády krále Jehojakima, ovšem považují jej za „vladaře, který vzhledem k neprriznivé politické situaci dosáhl maxima... a konsolidoval situaci svého územi' (Schipper, 2010: 221 in: Capek, 2018: 175)

$\mathrm{V}$ roce 605 př.o.l. (ve čtvrtém roce vlády krále Jehojakima) byl faraon Necho II. (v této době spojenec Asýrie) poražen babylónským vojskem. Vojsko vedl nejprve Nabopalasar (625-605) a později (po jeho onemocnění) jeho syn - korunní princ a spoluvládce Babylónie později nazývaný Nebúkadnesar II. K jeho porážce Egypta došlo v bitvě u Karchemiše. Ozvěny této bitvy zachytil prorok Jirmejahu (v básni proti Egyptu), Josephus Flavius (Josephus, 2005: X 11,1) i Babylónská kronika. (Nandrasky, 1994, 124). Novobabylónská říše tím získala nadvládu nad celou oblastí od Eufratu po Egypt: „A egyptský král už nikdy ze své země nevytáhl, protože babylónský král zabral od Egyptského potoka (Wadi el-Ariš) až $k$ řece Eufratu všechno, co předtím patřilo králi egyptskému. “ (2 Kr 24,7). Nadvláda Egypta tak byla v oblasti Sýrie a Judska ukončena. Úspěšné tažení Nebúkadnesara na západ bylo téhož roku (605 př.o.1.) ukončeno zprávou o smrti jeho otce Nabopolasara (626-604 př.o.1.). Tato událost přiměla Nebúkadnesara k návratu do Babylonu (604 př.o.1.), kde musel upevnit své pozice a nastoupit na královský trůn. Stal se králem po svém otci (vládl v letech 605-562 př.o.l.). V prvním desetiletí po svém nástupu na trůn podnikal výpravy do oblasti Sýrie a Judska. (Nandrasky, 1994: 124)

V roce 604 př.o.l. se Judsko a spolu s ním řada malých států (dřive vazalů Egypta) dobrovolně podrobuje nadvládě Novobabylónské říše. (Capek, 2018: 175). Po třech letech se Nebúkadnesar znovu vypravil na tažení proti Egyptu, tentokrát však úspěšný nebyl. Egyptské vojsko jej pod vedením Necha II. odrazilo nedaleko Aškalónu. Babylónské vojsko utrpělo velké ztráty. Neúspěch babylónského vojska využil král Jehojakim. Nedbal na varovné hlasy (Jirmejahu 36) a odmítl své vazalské povinnosti (pravděpodobně ve stejném roce nebo ve dvou následujících letech). Nebúkadnesar nezaútočil na Judsko bezprostředně poté, protože musel znovu vyzbrojit svou armádu po neúspěšném boji s Egyptem.

V roce 599 vytáhl Nebúkadnesar s vojskem do Sýrie a proti kmenům, které žily na východ od Sýrie a Judska (na tuto situaci reaguje pravděpodobně prorok Jirmejahu 49,28-33 výroky o Kédáru a Chácóru). (Nandrasky, 1994: 124). S př́mým útokem na Judsko zpočátku patrně váhal. Nejprve aktivizoval malé místní posádky (v této době 
stále vyzbrojoval svou armádou) tvořené mimo jiné hordami Aramejců, Moábců a Amónovců, které týraly a pustošily judskou zemi (2 Kr 24,2-7). Pravděpodobně šlo o „soldatesky umistěné babylónským králem na okupovaném území.., které z Nebúkadnesarova př́kazu vymáhaly vazalské poplatky /tribut/“. (Bic, 1980: 317318). Země byla již po nájezdech těchto soldatesek velmi zpustošená.

Nebúkadnesar se potom na krátký čas vrátil do Babylónu. Po svém návratu táhl přes Sýrii na Jeruzalém. (Nandrasky, 1994: 124) V roce 598 př.o.l. jeho vojsko oblehlo Jeruzalém (později již za vlády krále Jehojachina si jej poprvé podrobuje). Při obléhání města (na sklonku roku) král Jehojakim zemřel, takže si již neodpykal trest za svou vzpouru. Josephus Flavius se mylně domníval (na základě slov proroka Jirmejahu), že byl Jehojakim zabit Nabúkadnesarem a jeho mrtvé tělo bylo vyhozeno za hradby města (Josephus, 2005: X, 96-98). Za nepravděpodobnou je považována i tradice zachycená $\mathrm{v}$ Divrej hajamim bet (2 Pa 36,6-8), podle níž byl král v bronzových řetězech odveden do babylónského exilu (př́padně, že během této cesty zemřlel).

Králem se stal Jehojachin syn předchozího krále Jehojakima. Podle Melachim bet vládl Jehojachin (Jechonja či Jechonjahu) v Judsku tři roky (v období 598-597/598) př.o.l. Na trůn usedl jako osmnáctiletý mladík (2 Pa 24,8) nebo jako osmiletý chlapec (1 Pa 36,9). Rabínská tradice, která se snaží texty harmonizovat, se domnívá, že mladý král byl korunován dvakrát. Poprvé jako osmiletý, aby tak jeho otec zabránil sporům o trůn. Podruhé jako osmnáctiletý, když jeho otec zemřel. (Posner, 2019) Po třech měsících a deseti dnech odporu dal druhého adaru (roku 597) otevrrít brány Jeruzaléma: ,,Jójachín, král judský, vyšel ke králi babylónskému, on i jeho matka, jeho služebníci, velitelé $i$ dvořané. " (2 Kr 24,12). Jehojachin pravděpodobně předpokládal, že jej Nabúkadnesar ponechá na trůnu jako vazalského krále. Nebúkadnesar to podle midraše neučinil, protože věděl, že ,,pes nemǔže mít dobré potomstvo “. (Vajikra raba 19,6; Seder Olam raba 25).

$\mathrm{V}$ babylónské kronice uložené v Britském muzeu je porážka Jehojachina popsána slovy: „V sedmém roce, v měsíci kislev, přehližel babylónský král svá vojska, A když vpochodoval do zemé Chatti (Sýrie a Palestina), oblehl město Judovo (Jeruzalém) a druhého dne mésíce adar dobyl mésto a vzal krále do zajetí. Dosadil tam krále podle své vlastní volby, přijal jejich těžký tribut a poslal lobyvatelel do Babylonu." (Johnson, 1995: 81). Podle židovských legend se ve chvíli, kdy Nebúkadnesar vstoupil do Chrámu v Jeruzalémě, narodil jeho největší nepřítel perský král Darius. (Seder Olam, 1998).

Město, Chrám i královský palác byly poté podle Tanachu vyloupeny. (2 Kr 24,1013). Podle hodnocení historiků bylo „hlavní město... spiše jen symbolicky vyloupeno a zbaveno svého lesku než dobyto ". (Capek, 2018: 176). Horní vrstvy byly odvedeny do zajetí. V zemi byla ponechána pouze chudina - „dalat am haarec“ (2 Kr 24,14). Tento exil se označuje jako tzv. „první deportace“. (2 Kr 24,14-16; Jr 22,18-19). Mezi deportovanými byl podle Tanachu rovněž kněz a prorok Jechezkel. Oproti podání Tanachu se historikové domnívají, že „nejspíše jen malá část obyvatelstva je odvedena do Babylónie, zbytek zůstává... “"(Capek, 2018: 176).

Jehojachin byl za svou vzpouru v Babylónii uvězněn. Milost mu udělil (po 37 letech pobytu v zajetí) Evil-merodach (Avel/Amel Marduk jehož jméno má význam „Sluha/Ctitel“ nebo „Muž /boha/ Marduka“) nástupce a syn Nabúkadnesara v roce 562/1 př.o.l. Židé vlivem první části jeho jména „evil“ (odvozeno od slovesného kořene alef-vav-lamed - „byl pošetilý, byl hloupý“) museli jméno krále vnímat jako „Hlupák Merodach“ nebo „Śílenec Merodach“. (Heller, 2003: 42)

Výraz „evil“ však může být odvozen také od slovního kořene alef-jod-lamed. Poté by první část jména mohla znamenat „mocnář“, „vládce“, „princ“ (pak by význam jeho jména byl „Princ Merodach“) a „despota“ („Despota Merodach). Druhá část jména „Merodach“ odkazuje na nejvýznamnější babylónské božstvo té doby. Židé v tomto

XLinguae, Volume 13 Issue 3, June 2020, ISSN 1337-8384, ISSN 2453-711X 
jménu slyšeli hebrejský slovesný kořen mem-reš-dalet (,vzepřel se“). Jméno Merodach tak mohli chápat jako „Vzbouřenec“. (Heller, 2003: 42). Této akustické podobnosti využil midraš, když vypráví, jak se král Evil-merodach („Šílený vzbouřenec") postavil proti svému otci a prohlásil se králem. Otec jej však přemohl a dal uvěznit. (Vajikra raba 18,2). Podle rabínské tradice byl král Evil-merodach proslulý svými krutostmi, ale Jehojachina milostivě propustil. Podle židovských legend to učinil, protože jej s ním pojilo osobní přátelství (již za života jeho otce) nebo tak učinil na př́mluvu moudrého Daniela.

Jehojachin byl po ustanovení Evil-merodacha na trůn usazen mezi ostatními vazalskými králi, kteří žili v Babylónii. Jirmejahu uvádí, že byl mezi nimi dokonce králem vyvýšen: „Mluvil s ním vlídně a jeho křeslo dal postavit výše než křesla králů, kteři byli u něho v Babylóně. “ (Jr 52,32; srv. $2 \mathrm{Kr} 25,28)$ Spolu se svými pěti syny dostával př́děly z královského dvora. (Thomas, 1958: 84-86).

Někteří historikové se na základě nových archeologických nálezů klínových tabulek domnívají, že určité př́íděly získával zajatý král již o osm let dříve, což by znamenalo, že za vlády Evil-merodaka došlo pouze k navýšení těchto př́idělů.

Jehojachin žil se svou rodinou a družinou v Babylónii dlouho, protože byl deportován velmi mladý. Přesídlení Judejci datovali události, které zažívali ve vztahu k roku přesídlení svého krále. Z uvedeného je pravděpodobné, že Židé v Jójachínovi spatřovali posledního pravoplatného krále Judska. Rovněž v babylónských dokumentech je Jehojachin dále označován titulem „král Judska“.

Přes svou odbojnost se Judsko nestalo babylónskou provincií. Zůstalo vazalským státem. Králem byl ustanoven Jojachínův strýc, nejmladší syn krále Jóšijáše, bratr Jehojachima nerozhodný král Matanjahu (Matanja). Jméno Matanjahu („Dar Hospodinův") mu Nebúkadnesar změnil na Cidkijáhu (Cidkija), jehož význam je „(Má) spravedlnost (je) Hospodin“ (2 Kr 24,17). Cidkijahu byl poslední judský král. Vládl v období od roku 598/597 do roku 587/586 př.o.l. Vrchní vrstvy obyvatelstva byly již za vlády jeho předchůdce odvedeny do exilu. $Z$ toho důvodu měli jeho státní úruedníci velmi nízký původ (2 Kr 24,14-16). Cidkijáš obdobně jako jeho předchůdci podporoval modloslužbu. Dům Hospodinův byl v době jeho vlády poskvrněn $(2 \mathrm{Kr}$ $36,14)$. Neprosazoval spravedlnost a slova proroků neměl ve vážnosti. Zpočátku byl spojencem Babylónie. Falešní proroci (např. Chananja) v zemi intenzivně vyzývali k odporu (2 Kr 28,2-4). Své spojenectví v boji proti Babyloňanům mu nabídly také okolní státy (Tyrus, Sidon, Edom, Moáb) včetně egyptského krále Hofry (Ua-chabRé). Cidkijahu z počátku ujišt'oval babylónského krále o své věrnosti. Podporoval jej v tom prorok Jirmejahu (Jr 29,3).

V roce 594 př.o.l. vypukla v Babylónii vzpoura a vazalské státy na západě v tom viděly př́ležitost, jak se vymanit $\mathrm{z}$ područí Babylónie. S prosbou o pomoc se obrátily i na Judsko, kde stále existovala proti babylónská frakce. Král Cidkijahu (ve čtvrtém roce své vlády) navštívil Babylónii, pravděpodobně ve snaze zbavit se podezření $\mathrm{z}$ účasti na spiknutí (Jr 51,59). Nakonec však (v devátém roce své vlády) vypověděl babylónskému králi vazalskou poslušnost a přestal platit tribut (589 př.o.l.). Spolehl se především na pomoc Egypta (aktivně probíhala jednání s faraonem Hofrou), který však v té době s Babylónií nemohl soupeřit ani politicky ani vojensky. (Thomas, 1958: 214) Prorok Jirmejahu, který před tím krále varuje, byl považován za zrádce (Jr 27-29; 37,11-16).

V roce 589 přitáhlo do země přes Sýrii babylónské vojsko, dobylo města a vesnice v Judsku (s výjimkou několika pevností). V dubnu roku 589 př.o.l. byly napsány depeše vojenské hlídky štábnímu důstojníkovi v Lakíši (Lakíšská ostraka), které byly objeveny roku 1935. Jako poslední (před pádem Jeruzaléma) vzdorovala dvě města Lakíš a Azeka. Jak uvádí prorok Jirmejahu: „Vojsko babylónského krále bojovalo proti... všem zbylým judským městüm, proti Lakísi a Azece; z opevněných judských měst zůstala jen tato města. “(Jr 34,7). Tragičnost této chvíle dokládá nápis z Lakíše: 
„Necht' můj pán zví, že sledujeme signály z Lakýše, jak nám můj pán znameními uložil. Poněvadž již nevidíme Azeku... “. (Finkelstein - Silberman, 2007: 261)

Desátého tevetu (asara betevet) roku 588 př.o.l. vojsko oblehlo svaté město Jeruzalém. Tanach uvádí: „, V devátém roce Sidkijášova kralování, v desátém měsici, desátého dne toho mésice, přitáhl Nebúkadnesar, král babylónský, s celým svým vojskem proti Jeruzalému, položil se proti nému a zbudovali dokola obléhací val.“ (2 Kr 25,1 srv. Jr $52,4)$ Město bylo vyhladověno do takové míry, že se v něm začínají projevovat stopy kanibalismu. Po dočasném přerušení obléhání (vypořádání s egyptským vojskem) se vojáci vrátili (Jr 37,5.11). Jeruzalém byl po půldruhém roce zničen (,churban bajit rišon“) devátého avu (tiša beav) roku 587 př.o.l. (podle rabínské tradice 3338 let po stvoření světa). Mnoho lidí bylo pobito (,Zabil členy Sanhedrinu - velkého i malého, mládence a panny $i$ dèti... celkem 940000 lidí... dalši byli zabiti za městem a dalši zemřeli hladem" (BT, Gittin 57b). V knize Jirmejahu o tomto obyvatelstvu bylo řečeno: „Jako se špatnými fiky, které jsou tak špatné, že se nedaji jist, pravi Hospodin, právě tak naložím se Sidkijášem, králem judským, a jeho velmoži, $i$ pozůstatkem jeruzalémského lidu, s těmi, kdo zůstali v této zemi... “(Jr 24,8). Chrám byl vyloupen, zapálen a zbořen (od této doby již neexistují zprávy o arše úmluvy). Vydrancován a zničen byl pod vedením Nebúzaradána (velitel tělesné stráže babylónského krále) také královský palác, ostatní domy a hradby města. ( $2 \mathrm{Kr} 24,10$ 17; 25,3-4; 25,8; 2 Pa 36,17; Jr 52,6-7.12.28). Jak uvádí historikové: „Bylo po všem. Čtyři sta let judské existence skončilo v ohni a krvi. Babyloňané zcela zpustošili hrdé judské království, zničili jeho hospodářstvi a zcela rozvrátili judskou společnost... Náboženství i existence ... národa se mohly skončit touto ohromnou katastrofou. Jako zázrakem však jak izraelské náboženství, tak izraelský národ přežily.“ (Finkelstein Silberman, 2007: 262).

Král Cidkijáš prchající s jednotkami své osobní stráže z Jeruzaléma přes Judskou poušt' do Zajordání byl lapen u Jericha při přechodu Jordánského př́kopu (Jr 52,7-8). Odtud byl převezen do Nebúkadnesarova hlavního stanu (Nebúkadnesar sám se obléhání Jeruzaléma neúčastnil), který byl v Rivle (Rible) ve střední Sýrii (Jr 52,9). Poslední věc, kterou zde spatřil před tím, než jej Babylóňané oslepili (což byl „standardní trest pro vazala, který porušil př́sahu“ (Johnson, 1995: 81), byla poprava jeho synů $(\mathrm{Jr} 52,10)$. V Rivle byli rovněž popraveni mnozí úředníci a příslušníci horních vrstev obyvatelstva (Jr 52,10) včetně nejvyššího kněze $(2 \mathrm{Kr}$ 25,18-21). Král byl pak v řetězech odveden do vyhnanství v Babylónii, kde jeho stopa mizí. Rabínská literatura hodnotí jeho působení kladně (někdy pro něj dokonce používá výraz „cadik“), nezamlčuje však, že konal zlé věci (vytýká mu například, že nevaroval hř́šníky své generace). (BT, Sanhedrin 103a).

Obyvatelstvo bylo deportováno (druhá deportace) do Babylónie s výjimkou nejchudších vrstev. Chudí („dalej haam“) měli zůstat, aby vysazovali vinice a pracovali na poli. Žili prostým životem v babylónské provincii Judsko (zmenšenou o oblast Negevu a jižního Šefelu). (Berlejung, 2017: 189). Zůstat v Judsku mohli také bohatí obyvatelé, kteří zastávali pro babylónské (tedy proti egyptské postoje). V zemi rovněž zůstali Benjaminovci, kteří se pravděpodobně podřídili Babylónii již v roce 588 př.o.l. (z tohoto důvodu nebyla zničena města Gibeon, Mispa a Bétel). (Johnson, 1995: 82) Již před pádem Jeruzaléma odchází do Babylónie více než 800 osob, které se pravděpodobně přidaly na stranu nepřátel (Jr 52,29). Odchod obyvatelstva pokračuje ještě minimálně čtyři roky po dobytí Jeruzaléma, v jejichž průběhu z Judska do Babylónie odchází více než 700 obyvatel (Jr 52,30). Část obyvatelstva rovněž uprchla do Egypta a do východního Jordánska. Babyloňané do Judska nedosadili žádnou vrchní vrstvu obyvatelstva, která by nahradila deportované vyšší vrstvy (tím se situace v Judsku podstatně lišila od situace v Izraeli).

Po zničení Jeruzaléma byl v Judsku ustanoven za správce lidu Gedaljahu (Gedalja) ben Achikam. Jeho jméno bylo vyznavačské („Hospodin učinil velké věci“) a dobře

XLinguae, Volume 13 Issue 3, June 2020, ISSN 1337-8384, ISSN 2453-711X 
vyjadřovalo naděje, které v něj byly vkládány. Gedaljáš pocházel z významné rodiny. Byl přívržencem menší frakce umírněných (obdobně jako Jirmejahu a Baruch), kteří upřednostňovali mírovou spolupráci s Babyloňany (stáli proti početnější skupině radikálů, kteří požadovali boj a spoléhali na pomoc Egypta). Babyloňané zpravidla jmenovali správcem země, kterou si podmanili, některého z mužských př́ibuzných poraženého krále. $\mathrm{Z}$ toho důvodu se někteří rabíni domnívali, že Gedaljáš pocházel $\mathrm{z}$ davidovské dynastie. Historikové se oproti tomu domnívají, že to ,nemohl být někdo z davidovského rodu“. (Bic, 1983: 240)

Gedaljáš spolu se svými lidmi sídlil v Mispě (Jr 40,8.10), starobylém městě na severu Judska. Zde také představil svůj program obnovy: „,Nebojte se sloužit Kaldejcům. Zůstaňte v zemi, služte babylónskému králi a povede se vám dobře... Sklízejte víno, letni ovoce i olej, ukládejte do svých nádob a bydlete ve svých městech, která držite." (Jr 40,9-10). Ke Gedaljášovi se do sídelního města Mispy soustředili především chudí, kteří nyní dostali půdu a začali hospodařit jako vinaři a rolníci. Do země se také vrátilo mnoho uprchlíků z okolních zemí především z Edomu, Amonu a Moabu (Jr 40,11). Do Mispy přišel i prorok Jirmejahu, který se rozhodl v zemi zůstat, aby pomáhal Gedaljášovi ve správě země. Připojili se k nim také velitelé vojsk se svými muži a mnozí královští hodnostáři. Gedaljáš byl povinen Babyloňanům platit tribut. Nadvládu Babyloňanů v Judsku uznával a vyzýval lid ke spolupráci s jejich úředníky. Jeho správa země však trvala jen velmi krátce.

V sedmém měsíci (záříř̌ijen) 585 př.o.l. deset mužů (úředníci nebo důstojníci) v čele $\mathrm{s}$ Jišmaelem ben Netanjou, který poházel z královského potomstva $(\mathrm{Jr} 41,1)$, úkladně Gedaljáše zavraždili (Jr 41,1-9). Podle rabínské tradice $\mathrm{k}$ tomu došlo při oslavách Nového roku. Půst připomínající tuto událost byl odložen až na 3. tišri, aby nerušil oslavy. Motiv, který vedl k zavraždění Gedaljáše není v Tanachu výslovně zmíněn. Pravděpodobně jím mohla být Gedaljášova spolupráce s Babyloňany a jeho mírový program obnovy běžného života země.

Gedaljáše na zlé úmysly Jišmaela upozornil Jóchanan ben Kareach, který mu nabídl, že sám Jišmaela zavraždí, aby naděje na obnovu života $\mathrm{v}$ zemi nebyla zmařena (Jr 40,15). Bezelstný a čestný Gedaljáš to však odmítl. Obavy svých velitelů považoval za pouhou pomluvu („,lešon hara“). Talmud Gedaljáše chválí jako čestného muže, zároveň jej však kárá, že nedbal na varování svých přátel a byl tak zodpovědný nejen za svou smrt, ale i za smrt svých stoupenců.

Den po zavraždění Gedaljáše bylo (podle proroka Jirmejahu) zavražděno Jišmaelem ještě sedmdesát poutníků, kteří přišli do Mispy ze severoizraelských měst Šekemu, Šíla a Samaří s obětním darem a kadidlem pro Hospodina (Jr 41,4-9). Jejich mrtvá těla hodili do cisterny (Jr 41,7) uprostřed města (minimálně centrum města se tak stalo neobyvatelné). Poutníků bylo celkem osmdesát, ale deset z nich se zachránilo, když Jišmaelovi nabídli své skryté zásoby (Jr 41,8): „Těchto deset poutníků tím dalo najevo svi̊j nesouhlas s programem Gedaljášovým (žit v područi Babylóňanů v pokoji) a naznačovali ochotu přijmout program jiný (pokračování vodporu, pro nějž je třeba mít zásoby)." (Bic, 1983: 246) Následně Jišmael zajal královské dcery, dvořany, bojovníky a veškerý lid (včetně žen a dětí), který zůstal v Mispě (mezi zajatci byl i Jirmejahu a Baruch). V jakém roce k této události došlo je nejasné. Tanach uvádí pouze měsíc - sedmý (Jr 41,1). Většinou se předpokládá, že šlo o stejný rok, v jakém došlo ke zničení Chrámu, podle jiných historiků však k této události došlo později (maximálně však čtyři až pět let po pádu Chrámu).

Jochanan ben Kareach a další velitelé se shromáždili k boji proti Jišmaelovi. Dostihli ho u „Veliké vody“ v Gibeónu. K boji pravděpodobně ani nedošlo. Zajatci z Mispy se přidali na stranu Jochanana. Jišmael prchá do Zajordání. Snaží se dostat k Amónovcům od nichž vyšel popud k zavraždění Gedaljáše ( $\operatorname{Jr} 41,10-15)$. Jeho strach byl oprávněný, protože spolu s Gedaljášem a jeho muži byli povražděni také babylónští vojáci $(\mathrm{Jr} 41,3)$. 
Velitelé, kteři stáli na straně Gedaljáše, i lidé z Mispy měli rovněž obavy. Ani oni si nejsou jisti tím, jaká bude reakce Babylóňanů. Zvažují útěk do Egypta. Bůh (prostřednictvím proroka Jirmejahu) je před tím důrazně varuje ( $\mathrm{Jr} 42,1-22)$ : ,Jestliže se opět usidlite $v$ této zemi, budu vás budovat a nikoli bořit, zasadím vás a nevyvrátím... Jestliže řeknete: Nebudeme bydlet $v$ této zemi... piojdeme do zemé egyptské, kde neuvidíme válku a neuslyšíme zvuk polnice a nebudeme lačnèt po chlebu; tam budeme bydlet... Všichni muži, kteři maji v úmyslu vstoupit do Egypta, aby tam pobývali jako hosté, zemřou mečem, hladem či morem a žádný z nich nepřežije a neunikne tomu zlu, které na ně uvedu. " (Jr 42,10-17). Velitelé a lid z Mispy však jeho varování nedbali a hledají útočiště $v$ Egyptě. Usadili se v Tachpanchésu nedaleko hranic u východního ramene nilské delty (Jr 43,7). Do Egypta s nimi byl nedobrovolně odvlečen také prorok Jirmejahu a jeho přítel písař Báruch (Jr 43,1-7). Pro Hospodinova vyznavače musela být tato situace vnímána jako tragický zvrat dějin Izraele. Tyto dějiny začaly vyvedením lidu z egyptského otroctví ke svobodnému životu v zaslíbené zemi. A nyní se pozůstatky lidu svévolně vrací do Egypta. Mnozí z nich se také vrací k modlářskému způsobu života $(\mathrm{Jr} 44,15)$. V těchto teologických souvislostech zavraždění Gedaljáše přestává být malou osobní tragédií lokálního významu a stává se událostí srovnatelnou s pádem Chrámu a babylónským exilem.

Zavraždění Gedaljáše ukončilo období židovské samosprávy v zemi. Judejcům „zhasla posledni jiskra naděje“. (Kicur šulchan aruch 121,2) Judsko následkem zmíněných událostí téměř zpustlo. Konec Chrámu neznamenal úplný konec Hospodinova kultu (Tkac, 2018). Jeho tradice částečně pokračuje na místě trosek Chrámu, v místních svatyních, např. Mispa, Bét-el (Jr 41,5) a v domech, které unikly zkáze (zejména ve městech na sever od Jeruzaléma). (Berlejung, 2017: 189, 202).

Zničení Jeruzaléma, spálení Chrámu a porážka davidovské dynastie představuje velký otřes a „hluboký zlom v dějinách Izraele.“ (Rendtorrff, 1996: 82). Tato katastrofa byla interpretována jako trest, který postihl vyvolený lid za jeho neposlušnost a vzpurnost proti Bohu, který jej vyvedl z egyptského otroctví, aby jej nyní uvedl do babylónského zajetí. Zároveň je však tato kalamita vnímána jako počátek nových důrazů (možnost šíření slávy Hospodinovy mezi cizími národy). Chrámová bohoslužba končí a rozvíjí se bohoslužba bez obětí. Hledalo se však řešení, které by umožnilo realizaci micvot spojených s Chrámem a Zaslíbenou zemí ve chvíli, kdy jejich realizace byla zhola nemožná. A Židé řešení nalezli. Nerealizovatelné věci jsou neustále do nejmenších detailů studovány, připomínány a zpřítomňovány.

\section{Ozvěny zániku Judského království v židovském kalendáři}

V době tragických událostí (osobních i národních) člověk více než kdy jindy hledá svého Boha (2 S 12,16). Přemýšlí o sobě i o svém životě a zkoumá své skutky. Vzdává se věcí, které mu působí potěšení, zdržuje se jídla (někdy i pití), trhá svůj šat a obléká si prostý nekomfortní oděv (např. žíněné roucho) př́ípadně obuv, nepřevléká se (nenosí nový oděv), odkládá ozdoby a šperky, zachovává sexuální zdrženlivost, straní se lidí (usedá do prachu, sype si hlavu popelem), leží na zemi nebo na tvrdém či jinak nepohodlném lůžku, nemyje se (nebo jen ve studené vodě), modlí se, pláče, pokořuje se před Bohem (Kicur šulchan aruch 121,1) a činí pokání. Tomu se ř́ká půst. Obdobně se člověk chová také v době př́íprav na setkání s Bohem nebo jeho poslem.

Půst jako sebeponížení („,com“, „taanit“) a všechny jeho vnější doprovodné projevy jsou pouze př́ípravou na vnitřní proměnu. Tato proměna je zahájena pokáním. Hebrejské slovo „tešuva“ („pokání“) znamená „návrat“ a „odpověd”“. Je to návrat k Bohu, kdy se člověk přestává před svým Bohem skrývat. Člověk se vrací k Bohu a odpovídá mu dřive, než se jej Bůh zeptá: „Kde jsi? Proč ses skryl?“ (Gn 3).

Také později, když zlé pominulo, jsou tyto tragické události stále připomínány (či spíše zpřítomňovány) postními dny: „Naši moudři stanovili, že se máme postit ve

XLinguae, Volume 13 Issue 3, June 2020, ISSN 1337-8384, ISSN 2453-711X 
dnech, kdy naše předky postihly tragické události a katastrofy. “ (Kicur šulchan aruch $121,1$.$) Tak také zánik Judského království (pád prvního Chrámu a ztrátu národní$ suverenity) připomínají v židovském kalendáři čtyři veřejné postní dny („taanit cibur“): Půst desátého měsíce - „Asara betevet“ připomíná počátek Nebúkadnesarova obléhání Jeruzaléma r. 586 př.o.l. Půst čtvrtého měsíce - „Šiva asar betamuz“ připomíná prolomení hradeb Jeruzaléma r. 586 př.o.l. Půst pátého měsíce - „Tiša beav“ připomíná zničení Chrámu r. 586 př.o.l. (BT, Taanit 29a). Půst sedmého měsíce - „Com Gedalja“ připomíná zavraždění Gedaljáše (3. tišri), který byl guvernérem Judeje po zničení prvního Chrámu. Tři z těchto postních dnů („Asara betevet“, „Šiva asar betamuz“, „Com Gedalja“) se označují jako „malé“, protože jsou dodržovány od rozbřesku do soumraku. Čtvrtý půst („Tiša beav“) je dodržovaný od západu slunce do večera př́štího dne a proto se nazývá „velký“. Dva malé veřejné postní dny („Asara betevet“, „Šiva asar betamuz“) zpřítomňují události, které vedly k prvnímu churbanu (obležení Jeruzaléma, prolomení jeho hradeb). Třetí malý veřejný půst („Com gedalja“) připomíná zmaření všech nadějí na obnovení normálního života v zemi po prvním churbanu.

Důvodem zkázy Chrámu byl (podle rabínského judaismu) tragický obrat charakteru celého města (případně celé země), jak se projevoval v každodenním životě jeho obyvatel (nespravedlnost, útlak, korupce, duchovní úpadek). Tento zbídačený stav ve své době popisuje Jirmejahu: „Proběhněte ulicemi Jeruzaléma, prohledejte jeho náměstí, jen se dívejte a přesvědčte se, zda najdete někoho, kdo uplatňuje právo, kdo hledá pravdu, a já Jeruzalému odpustím. “ (Jr 5,1).

Chrám byl v době své existence nejen místem obětí, nýbrž také centrem vzdělávání, soudního systému, oslav poutních svátků a přinášení desátků. Centrum symbolizovalo čistotu, oddělenost pro Boha, národní jednotu, sociální spravedlnost a vymahatelnost práva. Rezignace na dodržování těchto ideálů vedlo ke zkáze Chrámu i města a ke ztrátě země.

Po zániku Judského království Židé v exilu (v Babylónii) postní dny na památku prvního churbanu pravděpodobně pečlivě dodržovali. Po návratu z exilu jejich dodržování začali někteří zpochybňovat (Za 7,3). Argumentovali tím, že po návratu do zaslíbené země a obnovení Chrámu není možné truchlit nad jejich ztrátou a zároveň oslavovat jejich znovunabytí. Proti zrušení těchto postních dnů se postavil prorok Zecharja. Učí lid, že i v době existence druhého Chrámu mají tyto dny svůj smysl a musí být stále zachovávány. Na rozdíl od předchozího období exilu to však již nejsou postní dny nýbrž radostné sváteční dny: ,,Toto pravi Hospodin zástupio: Pi̊st čtvrtého /tamuz/, pưst pátého /av/, půst sedmého /tišri/ a půst desátého mésice /tevet/ se judskému domu obrátí v radostné veseli a utěšené slavnosti. Jen milujte pravdu a pokoj!“ (Za 8,19). Stejné stanovisko se opakuje i v Ústní Tóře: „,V době pokoje (ješ šalom) budou /tyto dny/ pro radost..., ale v době, kdy není pokoj (ejn šalom), budou postními dny. " (BT, Roš hašana 18a,b) Raši (s odvoláním na rava Chanu bar Biznu) definuje dobu, kdy ,ješ šalom" (existuje pokoj/mír), jako dobu, kdy ,ješ mikdašs" (existuje Chrám) a dobu, kdy „ejn šalom“ (neexistuje pokoj/mír), jako dobu, kdy „ejn mikdaš‘ (neexistuje Chrám). Představu, že stejný den může být slaven bud' jako radostný nebo jako postní den (podle okolností), doplňuje rabi Papa o třetí možnost, kdy je možné si (za určitých okolností) vybrat: „Když je mír... tyto dny budou radostné..., $v$ době pronásledování... budou postními dny. V době, kdy nebude ani mír ani pronásledování... se lidé mohou postit, ale nemusí se postit... “ (BT, Roš hašana $18 b)$ V současné době mají tyto dny truchlivý charakter pro celou pospolitost. Menšinový názor nespojuje truchlivý charakter těchto dní primárně se zánikem Chrámu, nýbrž se ztrátou národní suverenity.

\section{Závěr}

Čtyři postní dny židovského kalendáře zpřítomňují zničení Chrámu („Tiša beav“), jakož i události, které k této katastrofě vedly („Asara betevet“, „Šiva asar betamuz“) a 
události, které bezprostředně následovaly („Com Gedalja“) a na dlouhou dobu ukončily všechny naděje. Připomínají člověku, že od pádu Chrámu, již není nic tak, jak by mělo být. Vyvolený lid prrišel o svou zemi, ztratil půdu, byl připraven o instituce, které zajišt'ovaly jeho náboženský, sociální, právní i ekonomický chod. Tím nejhorším však bylo, že byl ohrožen jeho charakter „Božího lidu“ i charakter jeho země jako „země zaslíbené“. Právě tato skutečnost (nikoliv ztráta hmotných statků) vzbuzuje v člověku nesmírnou lítost a bolest (Kardis, 2019) Smutek je v průběhu zmíněných postních dnů prožíván postupně - v tíživém nástupu, tragickém vrcholu i pomalém odeznění. (Katolo, 2018)

Zármutek však nemá poslední slovo. Již v odpolední modlitbě Mincha (v Amidě) v den postu „Tiša beav“ je př́tomna naděje a útěcha, která vrcholí následující sobotu. Tato sobota se nazývá „šabat nachamu“ (,šabat útěchy“). Haftara (čtení z Proroků) v tento den cituje Boží př́kaz, aby národy světa utěšily Boží lid: „Nachamu ami“ „Potěšte, potěste můj lid!" (Iz 40,1-26). „Šabat nachamu“ je první ze sedmi sobot útěchy, které po Tiša beav následují. Jejich hlavním motivem je obnova Jeruzaléma. Na konci těchto sedmi týdnů útěchy Židé slaví Roš hašana (Nový rok). Židé v exilu si tento den přejí, aby př́ští Nový rok již slavili v Jeruzalémě.

\section{Acknowledgments}

This article was published with the support of the Slovak Research and Development Agency under the contract No. APVV-17-0158.

The work is performed according to the Russian Government Program of Competitive Growth of Kazan Federal University.

This article was published with the support of International ScientificResearch Project: "Philosophy and religious studies and its meaning nowadays." Cooperation among: Sociedad Hispánica deAmigos de Kierkegaard, University of Granada (Spain) and Faculty of Humanities, University of Zilina in Zilina (Slovakia), 2020-2021.

\section{Bibliographic references}

BECKER, M. Transforming Sorrow to Joy: Rashi and the Four Fasts. Available online: https://www.haretzion.org/torah/yeshiva-publications/154-alei-etzion.

29.5.2019.

BENES, J. 2020. Plac Jeremjasuv. Praha: Advent-Orion. ISBN: 978-80-7172-634-0. BERLEJUNG, A. 2017. Nabozenske dejiny starovekeho Izraele. Praha: Vysehrad. ISBN 978-80-7429-281-1.

BIBLE. 2008. Písmo svate Stareho a Noveho zakona (vcetne deuterokanonickych knih). Cesky ekumenicky preklad. 14. vyd., Praha: Ceska biblicka spolecnost.

BIC, M. (ed.). 1980. Stary zakon. Preklad s vykladem. 6, Knihy kralovske, Druha Paralipomenon. Praha: Kalich.

BIC, M. (ed.). 1983. Stary zakon. Preklad s vykladem. XII., Jeremjas, Plac. Praha: Kalich.

CAPEK, F. 2018. Archeologie, dejiny a utvareni identity starovekeho Izraele. Praha: Vysehrad. ISBN 978-80-7601-082-6.

CAPEK, F. 2013. Dejiny Izraele a Judska v dobe kralovske. In: Martin Prudky, Jan Heller. Obtizne oddily Prednich proroku. Karmelitanske nakladatelství Kostelní Vydri: Karmelitanske nakladatelství, pp. 383-392. ISBN 9788071957249.

DIVECKY, J. 2006. Izrael soudcu a kralu. Praha: Nakladatelstvi P3K. ISBN 80903584-4-6.

DIVECKY, J. 2010. Kralove Izraele. Pribehy biblickych hrdinu. Praha: Nakladatelstvi P3K. ISBN 978-80-87186-07-7.

ELLIGER, K. - RUDOLPH, W. (ed.). 1990. Tora Neviim uchtuvim. Biblia Hebraica Stuttgartensia. Editio Funditus Renovata. Stuttgart: Deutsche Bibelgesellschaft. ISBN 978-3438052186. 
FEDER, R. 2007. Tisa beav - Devaty av. In Savua tov 39/5967, Holesov: Olam Spolecnost Judaica.

FINKELSTEIN, I. 2016. Zapomenute kralovstvi. Archeologie a dejiny severniho Izraele. Praha: Vysehrad. ISBN 978-80-7429-757-1.

FINKELSTEIN, I. - SILBERMAN, N. A. 2007. Objevovani Bible. Svata Pisma Izraele ve svetle moderni archeologie. Praha: Vysehrad. ISBN: 978-80-7021-869-3.

GANZFRIED, S. 2011. Kicur sulchan aruch. Praha: Agadah. ISBN 978-80-87571-002.

GANZFRIED, S. 2012. Kicur sulchan aruch. II. Praha: Agadah. ISBN 978-80-8757101-9.

GUGGENHEIMER, H. W. (ed.). 1998. Seder Olam. The Rabbinic View of Biblical Chronology. Oxford: Rowman and Littefield. ISBN 9780765760210.

HELLER, J. 2003. Vykladovy slovnik biblickych jmen. Praha: Advent-Orion. ISBN 80-7172-8?65-9.

HERZOG, CH. - GICHON, M. 1999. Biblicke valky. Brno: Jota-Nove obzory. ISBN 80-7242-053-4.

JACOBY, F. 1958. Die Fragmente der griechischen Historiker, III/C, Leiden: Brill.

JOSEPHUS, F. (BEGG, C.). 2005. Judean Antiquities, Leiden - Boston: Brill.

JEPSEN, A. 1997. Kralovska tazeni ve starem Orientu. Od Sinuheta k Nabukadnezarovi. Praha: Vysehrad.

JOHNSON, P. 1995. Dejiny zidovského naroda. Praha: Rozmluvy. ISBN 80-8533631-6.

KARDIS, M. 2019. The Presence of God - Certainty or Uncertainty? Religious Experience in the Biblical Tradition. In: Theologos, vol. XXI, n. 1, pp. 121-129. ISSN $1335-5570$.

KATOLO, A. 2018. Il medico e la terapia nell'Antico testamento. In: Theologos, vol. XX, n. 2, pp. 29-36. ISSN 1335-5570.

MALAMAT, A. 1988. The Kingdom of Judah between Egypt and Babylon. A Small State within a Great Power Confrontation. In: Classen, W. (ed.), Text and Context, Sheffield: Sheffield Academic Press, pp. 117-129. ISBN 1-85075-040-8.

NANDRASKY, K. 1994. Dejiny biblického Izraela. Bratislava: Bratislava: ECM. ISBN: 80-85733-16-1.

NOTH, M. 1950. Geschichte Israels, Goettingen: Vandenhoeck \& Ruprecht.

POSNER, M. How Old Was Jehoiachin? Availabale online: https://www.chabad.org/library/article_cdo/aid/1452602/jewish/How-Old-Was-

Jehoiachin.htm. 10.5.2019.

POTOK, CH. 2002. Putovani. Dejiny Zidu. Praha: Argo. ISBN: 80-7203-425-1.

RABINOVITCH, M. 2006. The Mishnah. New York: Mesorah Publications, Ltd.

RAHLFS, A. (ed.). 1935. Septuaginta, Id est Vetus Testamentum graece iuxta LXX interpretes, Stuttgart, Deutsche Bibelgesellschaft, 1935.

RENDTORFF, R. 1996. Hebrejska bible a dejiny. Uvod do starozakonni literatury. Praha: Vysehrad. ISBN 80-7021-190-3.

SKOLNIK, F. - BERENBAUM. M. 2007. Encyclopedia Judaical. 2. Vyd. Jerusalem: Thomson Gale, Keter Publishing House LTD. 17000 s. ISBN: 0028659287.

SOFER, Y.Ch. 1905. Kaf Hachaim, I. - X., Jerusalajim: Hotzaat Machon HaRishonim.

THOMAS, D. W. 1958. (ed.), Documents of Old Testament Times. London: Nelson.

TKAC, M. 2018. Vyvoj myslienky existencie chramu v Starom zakone. In: Theologos, vol. XX, n. 2, pp. 29-36. ISSN 1335-5570.

VRIES, S. P. 2008. Zidovske obrady a symboly. Praha: Vysehrad. ISBN 978-807021-963-8.

WISEMAN, D. J. 1956. Chronicles of Chaldean Kings., London: British Museum. MISNA. Available online: http://www.mechon-mamre.org/b/h/h0.htm, 20.1.2019. 
BEN MAJMON, M. Misne Tora. (RAMBAM). Available online: http://www.mechon-mamre.org/i/0.htm (20.1.2019).

MISNA BERURA. Available online: http://mishnaberura.eu5.org/ (20.1.2019).

Sulchan aruch, Orach chajim. Available online:

https://translate.google.cz/translate?hl=cs\&sl=iw\&u=https://www.sefaria.org/Shulcha n_Arukh,_Orach_Chayim\&prev=search (20.1.2019).

TALMUD BAVLI Available online: http://www.mechon-mamre.org/b/1/10.htm (20.1.2019).

Words: 6339

Characters: 43121 (23.96 standard pages)

ThDr. Marie Roubalova, ThD.

Hussite Theological Faculty

Charles University in Prague

Pacovska 350/4, 14000 Praha

Czech Republic

marie.roubalova@htf.cuni.cz

Assoc. Prof. Olga A. Kalugina

Department of Foreign Languages 102

Financial University under the Government of the Russian Federation

Leningradsky prospect 49125993 Moscow

Russia

kaluginaruc@mail.ru

Prof. ThDr. Roman Kralik

University of Zilina in Zilina

Faculty of Humanities

Univerzitna 1, 01026 Zilina

Slovak Republic

Institute of Psychology and Education

Kazan (Volga region) Federal University

18 Kremlyovskaya Str 420008, Kazan

Russia

kierkegaaard@centrum.cz

Doc. Dr. Peter Kondrla, PhD.

Faculty of Arts,

Constantine the Philosopher University in Nitra,

Hodzova 1, 94901 Nitra

Slovakia

pkondrla@ukf.sk 